\title{
Struktur Komunitas Collembola pada Tiga Tipe Habitat Sepanjang Daerah Aliran Sungai Brantas Hulu Kota Batu
}

\section{The Community Structure of Collembola in Three Type of Habitats along the Upstream Brantas River Basin of Batu City}

\author{
HUSAMAH ${ }^{*}$, FATCHUR ROHMAN $^{2}$, HEDI SUTOMO ${ }^{2}$ \\ ${ }^{1}$ Pendidikan Biologi FKIP Universitas Muhammadiyah Malang, Jl. Raya Tlogomas 246, Malang, Indonesia \\ ${ }^{2}$ Pendidikan Biologi Pascasarjana Universitas Negeri Malang, Jl. Semarang No. 5, Malang, Indonesia \\ *Email: usya_bio@yahoo.com
}

Manuscript received: 15 September 2015 Revision accepted: 4 Januari 2016

\begin{abstract}
Collembola is one of a group of animals that generally live in the soil. Collembola has an important role in the ecosystem due to its function as a subsystem of consumer and decomposition that can be used as bio-indicators. Changing in habitat in the upstream of Brantas River Basin is cause disruption for Collembola community. This is a descriptive research, aims to uncover the information of community structure, including the type found, diversity, evenness, and relative abundance of Collembola in three type habitats (forest, agricultural, and residential). Soil sampling conducted in each type of habitat using TBSF methods. Identification of Collembola samples conducted at the Biology Laboratory of University of Muhammadiyah Malang and verified at Basic Entomology Laboratory, Gadjah Mada University. This study results are; (1) the number of Collembola were found in forest were 21 , agriculture were 5, and residential were 17. (2) There is difference in descriptive diversity of Collembola in forest, agricultural, and residential. Collembola species diversity index of forest higher (2.78) compared to agriculture (1.16) and residential (2.42). Forest and residential habitat have moderate diversity, while agriculture has a low diversity. (3) There is difference in descriptive evenness of Collembola in forest, agricultural, and residential. Evenness index Collembola in forest was higher (0.91) than agriculture (0.72) and residential (0.85). Evenness of Collembola in residential is higher than agriculture. All types of habitat, including having a high evenness. (4) There are differences in the relative abundance of descriptive Collembola in forest, agricultural, and residential. Relative abundance of forest, agricultural, and residential varied. The highest relative abundance in forest is Hypogastrura consanguinea, Ascocyrtus sp, and Homidia cingula. The highest relative abundance in agriculture is Pseudachorutes javanicus, Isotomurus palustris, and Ascocyrtus sp. The highest relative abundance in residential is Ascocyrtus sp., Cryptopygus thermophilus, and Isotomurus palustris.
\end{abstract}

Keywords: bioindicator, brantas, collembola, river basin, soil

\section{PENDAHULUAN}

Ekosistem stabil umumnya ditempati organisme dengan diversitas yang tinggi. Berbagai jenis organisme berperan penting dalam menjaga stabilitas ekosistem melalui interaksinya yang kompleks dalam jaring-jaring makanan. Organisme yang sering dijumpai banyak berasosiasi dengan tanah dan tumbuhan adalah Collembola (Indriyati \& Wibowo, 2008).

Collembola merupakan contoh baik dari diversitas hewan tanah dan berperan penting dalam siklus nutrisi, dekomposisi bahan organik, dan formasi tanah, yang merupakan bagian penting ekosistem hutan. Kehadiran Collembola dipengaruhi oleh banyak aspek, yaitu $\mathrm{pH}$, aerasi, komposisi bahan organik, ketersiediaan nutrisi, jenis humus, struktur tanah, dan vegetasi (Zeppelini et al., 2009).

Sifat yang sensitif terhadap perubahan dan dinamika kondisi lingkungan menyebabkan Collembola sangat baik digunakan sebagai bioindikator kualitas lingkungan (Cassagne et al., 2003). Collembola selama ini banyak dikenal, tetapi penelitian tentang peran dan keberadaannya perlu terus dikembangkan (Indriyati \& Wibowo, 2008), salah satunya terkait dengan struktur komunitas Collembola dengan adanya perubahan lingkungan di Daerah Aliran Sungai (DAS).

Salah satu perubahan kondisi lingkungan dan termasuk di dalamnya perubahan kondisi tanah adalah di kawasan DAS Brantas Hulu Kota Batu. DAS Brantas Hulu merupakan wilayah konservasi, sehingga bentuk dan fungsinya harus selalu dijaga dan tidak dapat diubah (Jamilah, 2011).

Sebagian besar penduduk Kota Batu adalah petani. Mereka membudidayakan tanaman semusim atau tanaman hortikultura, berupa buah-buahan, sayuran, dan tanaman hias. Kegiatan budidaya berlangsung sepanjang tahun dengan input kimia yang tinggi dari pupuk dan pestisida sintesis (Indahwati et al., 2012). Masyarakat pun membuka lahan pertanian baru dengan membabat hutan di DAS. Seiring derasnya pembangunan, maka terjadi degradasi luas hutan dan peningkatan luas lahan perkebunan dan pemukiman. Berdasarkan latar belakang tersebut perlu kajian tentang struktur komunitas Collembola pada 3 tipe 
habitat sepanjang DAS Brantas Hulu Kota Batu. Artikel ini bertujuan untuk menganalisis, 1) jenis Collembola; 2) keanekaragaman Collembola; 3) kemerataan Collembola; dan 4) kelimpahan relatif Collembola pada habitat hutan, pertanian, dan pemukiman.

\section{METODE}

\section{Jenis Penelitian}

Penelitian ini adalah deskriptif, bertujuan mengungkap informasi indeks keanekaragaman jenis, indeks kemerataan jenis, dan kelimpahan relatif Collembola yang ditemukan pada tipe habitat hutan, pertanian, dan pemukiman sepanjang DAS Brantas Hulu Kota Batu.

\section{Waktu dan Tempat Penelitian}

Penelitian dilaksanakan pada Januari-Februari 2014 di Desa Sumber Brantas (hutan), Desa Pandanrejo (pertanian) dan Desa Torongrejo (pemukiman) Kota Batu.

\section{Populasi dan Sampel}

Populasi penelitian ini adalah populasi tak terhingga yaitu semua jenis Collembola di 3 tipe habitat. Sampel penelitian adalah Collembola pada 150 plot (1 habitat terdiri atas 50 plot). Teknik penentuan stasiun adalah purposive sampling dengan alasan, yaitu lokasi kemungkinan dijumpai Collembola, memenuhi pertimbangan tipe habitat, dan berada di sepanjang DAS Brantas Hulu Batu.

\section{Alat dan Bahan}

Alat yang digunakan adalah cangkul, skop, pisau, gunting, bak plastik, ayakan, kain blacu, kantong plastik, meteran, penggaris, Barlese Tullgrene modifikasi, GPS, cawan Petri, Beaker glass, alat tulis, mikroskop, kamera, patok, dan tali raffia. Bahan yang digunakan adalah formalin $4 \%$, aquades, sampel tanah, dan sampel Collembola.

\section{Pengumpulan Data}

\section{Penentuan Garis Transek dan Plot}

Penentuan garis transek dilakukan pada masing-masing stasiun. Transek pertama berjarak $10 \mathrm{~m}$ dari tepi sungai. Transek berjumlah 10 buah dengan panjang $50 \mathrm{~m}$ searah aliran sungai dan jarak antar transek 20 m (masing-masing 5 transek di kanan dan kiri sungai). Jumlah plot per stasiun adalah 50. Setiap garis transek terdiri dari 5 plot, 1 plot berukuran $25 \times 25 \times 30 \mathrm{~cm}$. Jarak antar plot $10 \mathrm{~m}$.

\section{Pengumpulan Sampel Tanah}

Pengambilan sampel tanah menggunakan Tropical Soil Biology and Fertility Method dan Hand Book Method, dengan langkah-langkah, yaitu 1) penetapan titik pengambilan contoh, 2) pengambilan contoh, dan 3) pemisahan fauna tanah (Anwar, 2007). Sampel tanah dibawa ke Lab. Biologi UMM. Penyortiran sampel menggunakan teknik Barlese Tullgren modifikasi.

\section{Identifikasi Sampel}

Sampel Collembola diamati menggunakan mikroskop. Sampel diidentifikasi sampai tingkat jenis, mengacu Hopkin (1997), Janssens (2010) dan Suhardjono et al
(2012). Sampel diverifikasi di Lab. Entomologi Dasar FP Universitas Gadjah Mada.

\section{Teknik Analisis Data}

Indeks keanekaragaman dihitung dengan rumus ShannonWiener, Indeks kemerataan dengan rumus Evennes, dan nilai kelimpahan relatif mengacu Suwarno et al (2013), sebagai berikut:

Rumus Shannon-Wiener:

$$
\mathrm{H}^{\prime}=-\sum \mathrm{pi} \ln \mathrm{pi}
$$

Rumus Evennes:

$$
\mathrm{E}=\frac{\mathrm{H}^{\prime}}{\ln \mathrm{S}}
$$

Rumus Kelimpahan Relatif:

$$
\mathrm{KR}=\frac{\text { kelimpahan jenis i }}{\text { total kelimpahan seluruh jenis }} \times 100 \%
$$

Indeks Shannon-Wiener dibagi dalam 5 kategori, yaitu $<1$ sangat rendah, $\geq 1-<2$ rendah, $\geq 2-<3$ sedang, $\geq 3$ $<4$ tinggi dan $\geq 4$ sangat tinggi (Odum, 1998; Maharadatunkamsi, 2011). Sementara Krebs (1989) mengelompokkan indeks kemerataan, yaitu $\mathrm{E} \leq 1$ tinggi, $0,4<\mathrm{E} \leq 0,6$ sedang, dan $\mathrm{E} \leq 0,4$ rendah.

\section{HASIL DAN PEMBAHASAN}

\section{Hasil}

Jenis Collembola pada Habitat Hutan, Pertanian, dan Pemukiman

Jenis-jenis Collembola yang ditemukan di tiap plot pada ketiga tipe habitat sepanjang DAS Brantas Hulu terlihat bervariasi, disajikan pada Tabel 1 .

Tabel 1. Jenis Collembola pada Semua Tipe Habitat

\begin{tabular}{llccc}
\hline \multirow{2}{*}{ No } & Jenis Collembola & \multicolumn{3}{c}{ Tipe Habitat } \\
\cline { 2 - 4 } & Hutan & $\begin{array}{c}\text { Pemuki } \\
\text { man }\end{array}$ & $\begin{array}{c}\text { Perta } \\
\text { nian }\end{array}$ \\
\hline 1 & Ascocyrtus sp & $\sqrt{ }$ & $\sqrt{ }$ & $\sqrt{ }$ \\
2 & Coecoloba sp & $\sqrt{ }$ & $\sqrt{ }$ & -- \\
3 & Collophora sp & $\sqrt{ }$ & $\sqrt{ }$ & -- \\
4 & Cryptopygus thermophilus & $\sqrt{ }$ & $\sqrt{ }$ & -- \\
5 & Entomobrya proxima & $\sqrt{ }$ & $\sqrt{ }$ & $\sqrt{ }$ \\
6 & Folsomia octoculata & $\sqrt{ }$ & $\sqrt{ }$ & -- \\
7 & Homidia cingula & $\sqrt{ }$ & -- & -- \\
8 & Hypogastrura consanguinea & $\sqrt{ }$ & $\sqrt{ }$ & -- \\
9 & Isotomurus palustris & $\sqrt{ }$ & $\sqrt{ }$ & $\sqrt{ }$ \\
10 & Lepidocyrtus vestitus & $\sqrt{ }$ & -- & -- \\
11 & Onychiurus fimetarius & $\sqrt{ }$ & $\sqrt{ }$ & -- \\
12 & Pseudachorutes javanicus & $\sqrt{ }$ & $\sqrt{ }$ & $\sqrt{ }$ \\
13 & Pseudisotoma sensibilis & $\sqrt{ }$ & -- & $\sqrt{ }$ \\
14 & Salina javana & $\sqrt{ }$ & $\sqrt{ }$ & -- \\
15 & Sminthurides aquaticus & $\sqrt{ }$ & $\sqrt{ }$ & -- \\
16 & Sphaeridia sp & $\sqrt{ }$ & $\sqrt{ }$ & -- \\
17 & Sphyrotheca dawydoffi & $\sqrt{ }$ & -- & -- \\
18 & Superodontela deharvengi & $\sqrt{ }$ & $\sqrt{ }$ & -- \\
19 & Thalassaphorura sp & $\sqrt{ }$ & $\sqrt{ }$ & -- \\
20 & Willemia sp & $\sqrt{ }$ & $\sqrt{ }$ & -- \\
21 & Xenylla orientalis & $\sqrt{ }$ & $\sqrt{ }$ & -- \\
\hline & & & &
\end{tabular}


Tabel 1 menunjukkan jenis Collembola pada habitat hutan berjumlah 21 , pemukiman 17 , dan pertanian 5 . Jumlah total jenis Collembola yang ditemukan pada semua habitat adalah 21. Ada beberapa temuan, yaitu 1) hanya ada 4 jenis yang ditemukan pada semua habitat, yaitu Ascocyrtus sp, E. proxima, I. palustris, dan P. javanicus, 2) jenis yang ditemukan di hutan dan tidak pada habitat lain ada 3, yaitu $H$. cingula, L. vestitus, dan S. dawydoffi, dan 3) jenis yang ditemukan di 2 habitat, yaitu $S$. aquaticus, $F$. octoculata, H. consanguinea, $C$. thermophilus, $S$. deharvengi, O. fimetarius, Collophora sp, Willemia sp, Thalassaphorura sp, X. orientalis, S. javana, E. proxima, Coecoloba sp, P. sensibilis, dan Sphaeridia sp.

\section{Keanekaragaman Collembola pada Habitat Hutan, Pertanian, dan Pemukiman}

Hasil penghitungan Indeks Keanekaragaman (H') Collembola menggunakan rumus Shannon-Wiener, yaitu pada habitat hutan sebesar 2,78 (sedang mendekati tinggi), habitat pertanian sebesar 1,16 (rendah), dan habitat pemukiman sebesar 2,42 (sedang). Hal ini berarti ada perbedaan secara deskriptif keanekaragaman Collembola pada tipe habitat hutan, pertanian, dan pemukiman, yang dapat dilihat pada Gambar 1.

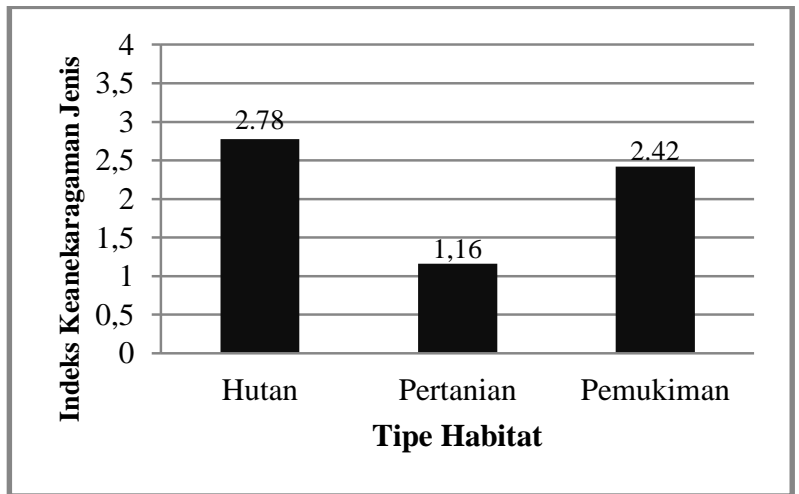

Gambar 1. Diagram Batang Indeks Keanekaragaman Collembola

Gambar 1 menunjukan keanekaragaman jenis Collembola pada habitat hutan lebih tinggi dari pertanian dan pemukiman. Gambar 1 juga menunjukkan keanekaragaman jenis Collembola pada habitat pemukiman lebih tinggi dari pertanian.

Kemerataan Collembola pada Habitat Hutan, Pertanian, dan Pemukiman

Hasil penghitungan Indeks Kemerataan (E) Collembola, yaitu pada habitat hutan sebesar 0,91 , pertanian 0,72 , dan pemukiman 0,85 . Ini berarti, ada perbedaan secara deskriptif kemerataan Collembola pada habitat hutan, pertanian, dan pemukiman. Perbedaan tersebut dapat dilihat pada Gambar 2.

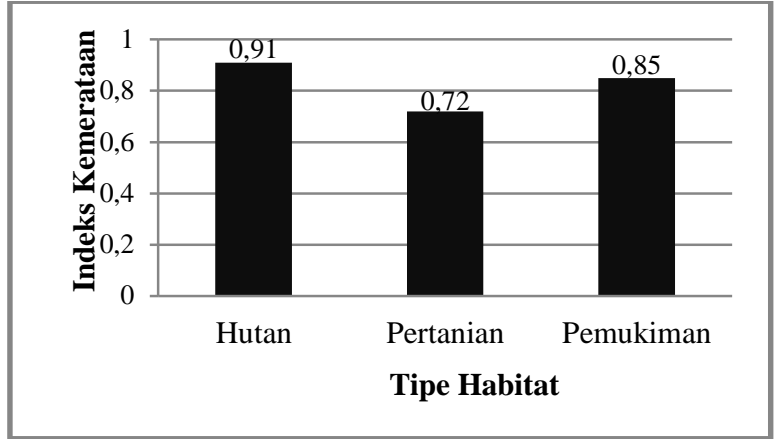

Gambar 2. Diagram Batang Indeks Kemerataan Collembola

Gambar 2 menunjukkan bahwa kemerataan Collembola pada habitat hutan lebih tinggi dibandingkan kemerataan pada habitat pertanian dan pemukiman. Kemerataan Collembola pada habitat pertanian lebih tinggi dari pemukiman. Namun demikian, semua tipe habitat termasuk kategori kemerataan tinggi.

\section{Kelimpahan Relatif Collembola pada Habitat Hutan,}

Pertanian, dan Pemukiman

Hasil perhitungan kelimpahan relatif Collembola yang ditemukan pada 3 tipe habitat disajikan pada Tabel 2.

Tabel 2. Nilai Kelimpahan Relatif Setiap Tipe Habitat

\begin{tabular}{clccc}
\hline \multirow{2}{*}{$\mathbf{N}$} & & \multicolumn{3}{c}{$\begin{array}{c}\text { Nilai Kelimpahan Relatif } \\
\text { Tipe Habitat }\end{array}$} \\
\cline { 3 - 5 } (\%)
\end{tabular}

Tabel 2 menunjukkan nilai kelimpahan relatif pada habitat hutan dari tertinggi sampai terendah, yaitu $H$. consanguinea (12,4\%), Ascocyrtus sp (11,4\%), H. cingula 
(10,7\%), X. orientalis $(10,4 \%)$, I. palustris $(9,4 \%), C$. thermophilus $(7,4 \%)$, E. proxima $(5,0 \%)$, Coecoloba $\mathrm{sp}$ $(4,0 \%)$, S. deharvengi $(3,5 \%)$, Collophora sp (3,4\%), S. javana (2,8\%), Sphaeridia sp (2,5\%), Thalassaphorura $\mathrm{sp}$ $(2,3 \%), O$. fimetarius $(2,1 \%), P$. sensibilis $(2,0 \%)$, Willemia sp (1,9\%), S. dawydoffi $(1,9 \%)$, L. vestitus $(1,9 \%)$, F. octoculata (1,9\%), S. aquaticus $(1,9 \%)$, dan P. javanicus $(1,5 \%)$.

Nilai kelimpahan relatif pada habitat pertanian dari tertinggi sampai terendah, yaitu $P$. javanicus $(42,3 \%), I$. palustris $(32,7 \%)$, Ascocyrtus sp $(22,7 \%)$, P. sensibilis $(1,8 \%)$, dan E. proxima $(0,5 \%)$. Adapun jenis lain memiliki nilai kelimpahan relatif $0 \%$ karena tidak ditemukan. Nilai kelimpahan relatif pada habitat pemukiman, yaitu jenis Ascocyrtus sp (34,6\%), C. thermophilus (10,0\%), I. palustris $(7,3 \%)$, dan $X$. orientalis $(6,5 \%) . F$. octoculata $(4,4 \%), O$. fimetarius $(4,4 \%)$, dan $H$. consanguinea memiliki nilai $4,4 \%$. Jenis Coecoloba sp memiliki nilai $3,4 \%$, Collophora sp (2,8\%), dan Thalassaphorura sp (2,5\%). Willemia sp, S. aquaticus, dan S. javana memiliki nilai $2,2 \%, S$. deharvengi $(1,8 \%)$, dan E. proxima serta Sphaeridia sp memiliki nilai $1,5 \%$. Adapun jenis lain memiliki nilai kelimpahan relatif $0 \%$ karena tidak ditemukan.

Berdasarkan Tabel 2, kelimpahan relatif Collembola tertinggi pada habitat hutan adalah jenis $H$. consanguinea, Ascocyrtus sp, dan $H$. cingula. Kelimpahan relatif Collembola tertinggi pada habitat pertanian adalah jenis $P$. javanicus, I. palustris, dan Ascocyrtus sp. Sementara itu, kelimpahan relatif Collembola yang tertinggi pada habitat pemukiman adalah jenis Ascocyrtus sp., C. thermophilus, dan I. palustris. Tabel 2 juga menunjukkan perbedaan secara kelimpahan relatif setiap jenis pada 3 habitat. Ada 12 jenis pada habitat hutan yang memiliki nilai kelimpahan relatif lebih tinggi dibandingkan habitat lain. Ada 3 jenis Collembola pada pertanian yang memiliki nilai kelimpahan relatif lebih tinggi dibandingkan habitat lain. Ada 7 jenis Collembola pada pemukiman yang memiliki nilai kelimpahan relatif lebih tinggi dibandingkan habitat lain.

\section{Pembahasan}

\section{Jenis Collembola pada Habitat Hutan, Pertanian, dan Pemukiman}

Jumlah total jenis Collembola yang ditemukan pada semua habitat adalah 21. Jenis-jenis tersebut dapat dikelompokkan dalam 11 suku, yaitu Hypogastruridae, Isotomidae, Odontellidae, Entomobryidae, Sminthurididae, Onychiuridae, Arrhopalitidae, Neanuridae, Paronellidae, Sminthuridae, dan Sminthurididae.

Ada 21 jenis Collembola yang ditemukan pada habitat hutan, sedangkan pertanian 5 (3 suku: Entomobryidae, Isotomidae, dan Neanuridae) dan pemukiman 17 (9 suku: Hypogastruridae, Isotomidae, Odontellidae, Entomobryidae, Sminthurididae, Onychiuridae, Arrhopalitidae, Neanuridae, dan Paronellidae). Jumlah jenis dan jumlah suku yang ditemukan dalam penelitian ini relatif tinggi karena Collembola memang memiliki distribusi luas. Menurut Amir (2008) distribusi Collembola sangat luas, dapat ditemukan di berbagai habitat seperti kutub, gurun, sub tropis, dan tropis. Distribusi Collembola dapat terjadi dengan bantuan partikel tanah dan bahan organik, angin, dan air. Beberapa jenis Collembola memiliki sebaran kosmopolit, meski ada yang endemisme tinggi.

Data jumlah jenis menunjukkan beberapa hal penting terkait distribusi Collembola. Jenis paling banyak ditemukan adalah dari suku Entomobryidae (4 jenis), Isotomidae (4 jenis), dan Hypogastruridae (3 jenis). Indriyati \& Wibowo (2008) menemukan 3 suku dominan di lahan sawah organik dan konvensional, yaitu Entomobryidae, Isotomidae, dan Hypogastruridae. Menurut Kanal (2004) lahan perlakuan rotasi tanaman, pemupukan, dan pergantian kondisi iklim tahunan didominasi Entomobryidae, Isotomidae, dan Onychiuridae.

Entomobryidae merupakan suku dominan dan terbesar dari Collembola dengan lebih dari 1625 jenis telah teridentifikasi (Bellini \& Zeppelini, 2008). Entomobryidae mampu berdaptasi dan bertahan hidup, ditemukan pada lapisan serasah atau dekat permukaan (Elisa et al., 2013). Jenis makanan Entomobryidae bervariasi (Indriyati \& Wibowo, 2008). Hypogastruridae juga terdistribusi sangat luas, sedang Isotomidae sering terdapat dalam jumlah banyak di hutan basah (Noerdjito, 2010).

Jenis yang ditemukan pada semua tipe habitat yaitu Ascocyrtus sp., E. proxima, I. palustris, dan P. javanicus. Jenis hanya ada di hutan adalah $H$. cingula, L. vestitus, dan S. dawydoffi. Jenis lain ditemukan di 2 habitat. Menurut Suhardjono et al (2012) faktor-faktor lingkungan berpengaruh terhadap kehadiran dan pemilihan tempat hidup Collembola. Setiap habitat mempunyai kombinasi atau perangkat faktor berbeda. Setiap faktor atau kombinasi faktor mempunyai pengaruh berbeda pada jenis atau kelompok jenis, baik menguntungkan maupun merugikan. Daerah geografi yang memiliki pola iklim, vegetasi, dan faktor lain yang berbeda dihuni oleh jenis berbeda dan dengan komposisi keanekaragaman berbeda pula.

Jenis Collembola yang ditemukan dalam penelitian ini adalah jenis yang sebelumnya telah dilaporkan ditemukan para peneliti di Indonesia. Jumlah jenis yang ditemukan relatif lebih tinggi dibandingkan dengan hasil penelitian sebelumnya. Rahmawati (1999) menemukan 17 jenis Collembola (4 suku). Suku dominan, yaitu Entomobryidae dan Isotomidae. Jumlah jenis lebih banyak dibandingkan Suharjono (1992) yang hanya memperoleh 5 jenis, yaitu $C$. thermophilus (paling melimpah), Pseudachorutes sp., Tullbergia sp., F. onychiurina, dan I. trispinata (paling sedikit).

Temuan menarik penelitian ini adalah jenis dan suku pada pemukiman secara umum lebih beragam dibandingkan pertanian. Ini dimungkinkan karena di pemukiman masih terdapat vegetasi tetap berumur panjang dan menghasilkan banyak serasah. Vegetasi di pemukiman, yaitu sengon, pisang, kelapa, nangka, dan tanaman holtikultura. Keberadaan vegetasi ini mendukung distribusi Collembola sehingga jenis yang ditemukan lebih beragam. Sementara itu, vegetasi pada pertanian adalah tanaman holtikultura, seperti bawang merah, ubi jalar, sawi, terong, tomat, dan jagung. Tanaman ini relatif tidak menghasilkan serasah karena langsung dipanen dan dibersihkan petani. Penggunaan pestisida sintesis dan pengolahan tanah juga 
menghambat distribusi Collembola, sehingga jenis yang ditemukan sedikit. Temuan ini sesuai Rahmadi et al (2004) bahwa faktor biotik seperti tumbuhan berpengaruh terhadap keberadaan Collembola. Keanekaragaman tumbuhan mempengaruhi kondisi tanah sehingga juga mempengaruhi keberadaan Collembola.

\section{Keanekaragaman Jenis Collembola pada Habitat Hutan, Pertanian, dan Pemukiman}

Nilai indeks keanekaragaman jenis digunakan untuk membandingkan komposisi jenis dari ekosistem atau komunitas yang berbeda (Indahwati et al., 2012). Berdasarkan paparan hasil, ada perbedaan secara deskriptif keanekaragaman Collembola tanah pada habitat hutan, pertanian, dan pemukiman. Habitat hutan dan pemukiman termasuk memiliki keanekaragaman sedang, sedangkan habitat pertanian termasuk rendah.

Nilai tersebut menunjukkan bahwa habitat hutan lebih subur dan lebih mendukung kehidupan Collembola dibandingkan pertanian dan pemukiman. Menurut Erniyani et al (2010) terkait kajian kesuburan tanah, semakin tinggi indeks keanekaragaman semakin tinggi tingkat dekomposisi, sehingga kesuburan tanah semakin baik/tinggi. Menurut Suwondo (2002) bila indeks keanekaragaman hewan tanah besar berarti tingkat dekomposisi tinggi, dan begitu pula sebaliknya.

Keanekaragaman hewan tanah lebih tinggi di hutan dibandingkan dengan daerah yang terbuka. Komposisi hewan tanah pada hutan dan ladang atau pertanian tidak sama karena perbedaan kandungan C-organik tanah. Hewan tanah sebagai komponen biotik pada ekosistem tanah sangat tergantung pada lingkungan. Perubahan lingkungan berpengaruh terhadap kehadiran hewan dan perubahan faktor fisika-kimia tanah berpengaruh terhadap kehadiran jenisnya. Keanekaragaman hewan tanah lebih rendah pada daerah yang terganggu daripada daerah yang tidak terganggu (Suin, 2012).

Nilai indeks keanekaragaman jenis Collembola pada habitat pemukiman termasuk kategori sedang dan lebih tinggi dari tipe habitat pertanian, meskipun tetap lebih rendah dari hutan. Hal ini berarti Collembola pada pemukiman mampu beradaptasi sehingga bertahan hidup. Beberapa kondisi yang dibutuhkan sebagai persyaratan hidup mampu ditoleransi. Menurut Suwondo (2006) sebagian Collembola mampu mengadakan interaksi dengan faktor lingkungan. Faktor lingkungan menentukan struktur komunitas Collembola karena pada komunitas itu Collembola saling berinteraksi. Perbedaan keanekaragaman menunjukkan tingkat toleransinya terhadap lingkungan.

Lebih tingginya nilai keanekaragaman jenis pada habitat pemukiman didukung masih adanya vegetasi tetap atau berumur panjang yang menghasilkan serasah relatif banyak. Tumbuhan yang umumnya ditemukan di tipe habitat pemukiman ini adalah sengon, pisang, kelapa, nangka, dan tanaman holtikultura. Tumbuhan tersebut terdapat dipekarangan rumah penduduk atau di daerah sekitar pemukiman. Menurut Rahmadi et al (2004) faktor biotik juga berpengaruh terhadap keberadaan Collembola. Vegetasi penutup merupakan faktor penting karena mempengaruhi keadaan tanah dan perilaku hidup hewan tanah.

Berdasarkan nilai indeks keanekaragaman maka dapat dikatakan habitat hutan lebih stabil dibandingkan pertanian dan pemukiman. Hal yang menarik adalah pemukiman ternyata lebih stabil dibandingkan pertanian. Alasan paling kuat adalah adanya vegetasi sebagaimana telah dijelaskan sebelumnya. Keanekaragaman identik dengan kestabilan ekosistem, yaitu jika keanekaragaman ekosistem tinggi, maka kondisi ekosistem tersebut cenderung stabil. Keadaan tersebut menyebabkan rantai-rantai makanan lebih panjang, lebih banyak simbiosis, interaksi lebih besar yang mengurangi gangguan dan meningkatkan kemantapan.

\section{Kemerataan Collembola pada Habitat Hutan, Pertanian, dan Pemukiman}

Data kemerataan menunjukkan tingkat penyebaran individu jenis-jenis yang ada (Leksono, 2011). Berdasarkan paparan hasil, ada perbedaan secara deskriptif kemerataan Collembola pada habitat hutan, pertanian, dan pemukiman. Kemerataan Collembola pada habitat hutan lebih tinggi dibandingkan pada pertanian dan pemukiman. Kemerataan Collembola pada habitat pemukiman lebih tinggi dari pertanian.

Nilai indeks kemerataan menjadi informasi ada tidaknya dominansi suatu jenis (Krebs, 1989). Merujuk kategori Krebs, maka semua tipe habitat memiliki kemerataan tinggi. Berdasar kategori tersebut, semua habitat memiliki distribusi jenis yang merata dan tidak ada dominasi jenis tertentu.

Tingginya indeks kemerataan mengindikasikan kelimpahan jenis yang merata, sedangkan indeks kemerataan rendah mengindikasikan kecenderungan dominasi jenis tertentu (Priyono \& Abdullah, 2013). Apabila populasi suatu suku tidak dominan maka kemerataan cenderung tinggi. Komponen lingkungan mempengaruhi kemerataan biota, sehingga tingginya kemerataan jenis dapat menunjukkan kualitas habitat (Fachrul, 2012).

Penelitian ini menunjukkan indeks kemerataan jenis pada setiap habitat berbeda secara deskriptif. Kamal et al (2011) menduga ini dipengaruhi oleh rantai makanan, yaitu semakin panjang rantai makanan, maka nilai indeks kemerataan semakin tinggi. Kemerataan cenderung meningkat mengikuti keragaman struktur habitat.

Apabila membandingkan nilai indeks kemerataan antar habitat, dapat dikatakan bahwa Collembola pada pertanian cenderung mendominasi meskipun dalam kadar sangat rendah. Menurut Indriyati \& Wibowo (2008) sistem pertanian dengan aplikasi pestisida secara berlebihan dapat menekan populasi Collembola. Penggunaan insektisida yang intensif pada pelaksanaan budidaya konvensional telah menekan populasi Collembola.

Endlweber et al (2006) mengaplikasikan insektisida klorpirifos dan dimetoat melalui daun dan tanah. Ia mendapati adanya pengaruh signifikan dari kedua jenis bahan aktif insektisida tersebut dalam menekan kepadatan populasi Collembola, mengubah dominasi jenis, meski komposisi jenis Collembola tidak berubah. 
Kelimpahan Relatif Collembola pada Tipe Habitat Hutan, Pertanian, dan Pemukiman

Kelimpahan relatif jenis pada tipe habitat hutan, pertanian, dan pemukiman bervariasi dan memiliki perbedaan secara deskriptif. Kelimpahan relatif tertinggi pada tipe habitat hutan adalah $H$. consanguinea, Ascocyrtus sp, dan $H$. cingula. Kelimpahan relatif tertinggi pada habitat pertanian adalah $P$. javanicus, I. palustris, dan Ascocyrtus sp. Kelimpahan relatif tertinggi pada habitat pemukiman adalah Ascocyrtus sp., C. thermophilus, dan I. palustris. Dapat dikatakan Ascocyrtus sp cenderung memiliki kelimpahan tinggi pada semua habitat.

Ascocyrtus sp memiliki distribusi yang luas di Asia Tenggara dan kawasan Oseania. Ascocyrtus sp. tersebar luas di Indonesia, khususnya di Maluku, Timor, Papua, Lombok, Sumatera, Sulawesi, dan Jawa (Suhardjono dkk, 2012). Ascocyrtus sp juga ditemukan melimpah di Thailand (Kim et al., 1999) dan Himalaya India. Ascocyrtus sp. memiliki jumlah individu tertinggi (Bhagat, 2013). Ascocyrtus sp bahkan ditemukan di habitat gua dan pertanian gandum New South Wales serta North East Herald Australia (Greenslade \& Farrow, 2008).

Secara umum dapat dikatakan bahwa habitat hutan cenderung mendukung kehidupan Collembola tanah dibandingkan habitat yang lain. Habitat hutan lebih stabil dan memiliki kompleksitas jaring-jaring makanan. Menurut Price (1997) pada ekosistem yang memiliki kelimpahan tinggi, di dalamnya terdapat interaksi kompleks dalam hal jaring-jaring makanan yang dapat menunjang stabilitas. Hal ini sesuai dengan Odum (1998) bahwa pada ekosistem yang stabil umumnya terdapat kompleks organisme dengan kelimpahan yang tinggi. Lahan yang vegetasinya beranekaragam dan rapat, kelimpahan hewan tanahnya akan tinggi (Suin, 2012).

Populasi hewan dalam tanah erat hubungannya dengan kadar bahan organik. Penelitian Fitrahtunnisa \& Ilhamdi (2013) menunjukkan kelimpahan arthropoda tanah berkorelasi dengan faktor lingkungan abiotik di setiap habitat seperti ketebalan serasah, kandungan bahan organik tanah, kandungan air tanah, suhu, dan kelembaban udara.

Perubahan komposisi floristik atau tumbuhan pada suatu habitat akan berpengaruh pada kelimpahan arthropoda yang berada di dalamnya, yang pada akhirnya dapat mengganggu stabilitas ekosistem tersebut (Trisnawati \& Subahar, 2011). Perubahan lingkungan akan berpengaruh secara langsung maupun tidak langsung terhadap fauna yang menghuninya (Rahmadi \& Suhardjono, 2007).

Kelimpahan Collembola ditentukan oleh sistem pertanian yang diterapkan. Sistem pertanian dengan aplikasi pestisida secara berlebihan dapat menekan populasi Collembola, sebaliknya sistem pertanian yang ramah lingkungan, seperti sistem pertanian organik akan menciptakan keadaan yang mendukung bagi kelangsungan hidup Collembola. Hasil penelitian Indriyati \& Wibowo (2008) menunjukkan kelimpahan Collembola pada lahan organik ternyata lebih tinggi dibandingkan pada lahan konvensional. Diduga penggunaan insektisida yang intensif pada pelaksanaan budidaya tanaman padi konvensional telah menekan populasi Collembola.

\section{KESIMPULAN}

Jumlah jenis Collembola habitat hutan 21, pertanian 5, dan pemukiman 17. Hutan dan pemukiman memiliki keanekaragaman sedang namun pertanian rendah. Semua habitat memiliki kemerataan tinggi, hutan memiliki kemerataan lebih tinggi dari pertanian dan pemukiman, namun pemukiman lebih tinggi dari pertanian. Kelimpahan relatif bervariasi, hutan tertinggi adalah $H$. consanguinea, Ascocyrtus sp, dan $H$. cingula; pertanian tertinggi adalah $P$. javanicus, I. palustris, dan Ascocyrtus sp; dan pemukiman tertinggi adalah Ascocyrtus sp., C. thermophilus, dan $I$. palustris. Hasil penelitian ini dapat menjadi acuan penelitian lain terkait struktur dan fungsi Collembola pada ekosistem berbeda.

\section{UCAPAN TERIMA KASIH}

Publikasi ini bagian dari tesis di Pendidikan Biologi Pascasarjana Universitas Negeri Malang dan didanai Universitas Muhammadiyah Malang, sehingga ucapan terima kasih kepada Rektor dan jajarannya patutlah dihaturkan. Terima kasih pula kepada Dr. Suputa yang membantu verifikasi sampel Collembola di Lab. Entomologi Dasar FP UGM.

\section{REFERENSI DAN SITASI}

Amir, A.M. (2008). Peranan serangga ekor pegas (Collembola) dalam rangka meningkatkan kesuburan tanah. Warta, 14(1), 16-17.

Anwar, E.K. (2007). Pengambilan contoh untuk penelitian fauna tanah. Dalam Saraswati, R. Husen, E. \& Simanungkalit, R.D.M. (Eds). Metode analisis biologi tanah. Jakarta: BB Litbang Sumberdaya Lahan Pertanian, Departemen Pertanian.

Bellini, B.C. \& Zeppelini, D. (2009). A new species of Seira (Collembola: Entomobryidae) from Northeastern Brazil. Revista Brasileira de Zoologia, 25(4), 724-727.

Bhagat, R.C. (2013). Diversity and checklist of Collembola-Fauna (Insecta) of Jammu, Kashmir and Ladakh Himalaya, India. Cibtech Jour. of Zoology, 2(2), 31-35.

Cassagne, N., Gers, C. \& Gauquelin, T. (2003). Relationships between Collembola, soil chemistry and humus types in forest stands (France). Biol Fertil Soils, 37:355-361.

Elisa, F., Jasmi \& Abizar. (2013). Komposisi serangga tanah pada kebun karet di Nagari Padang XI Punggasan Kecamatan Linggo Saribaganti Kabupaten Pesisir Selatan. Laporan Penelitian. Padang: STKIP PGRI.

Endlweber, K., Schadler, M. \& Scheu. S. 2006. Effects of foliar and Soil Insecticide applications on the Collembolan community of An Early Set-Asidearable Field. Appl. Soil Ecology, 31(1\&2), 136-146.

Erniwati. (2008). Fauna tanah pada stratifikasi lapisan tanah bekas penambangan emas Jampang, Sukabumi Selatan. Zoo Indonesia, 17(2), 83-91. 
Erniyani, K., Wahyuni, S. \& Pu'u, Y.M.S.W. (2010). Struktur komunitas mesofauna tanah perombak bahan organik pada vegetasi kopi dan kakao. Agrica, 3(1), 18.

Fachrul, M.F. (2012). Metode sampling bioekologi. Edisi 1 Cetakan III. Jakarta: Bumi Aksara.

Fitrahtunnisa \& Ilhamdi, M.L. (2013). Perbandingan keanekaragaman dan predominansi fauna tanah dalam proses pengomposan sampah organik. J. Bumi Lestari, 13(2), 413-421.

Fountain, M.T., Brown, V.K., Gange, A.C., Symondson, W.O.C. \& Murray, P.J. (2007). The Effects of the insecticide chlorpyrifos on spider and Collembola communities. Pedobiologia, 51(2), 147-158.

Greenslade, P. \& Farrow, R. (2008). Coringa-Herald National Nature Reserve-Identification of invertebrates collected on the 2007 invertebrate survey. Canberra City: Australian Government Department of the Environment, Water, Heritage and the Arts.

Hopkin, S.P. (1997). Biology of the springtails (Insecta: Collembola). Oxford: Oxford University Press.

Indahwati, R., Hendrarto, B. \& Izzati, M. (2012). Keanekaragaman Arthropoda tanah di lahan apel Desa Tulungrejo Kecamatan Bumiaji Kota Batu. Makalah Seminar Nasional Pengelolaan SDA dan Lingkungan, UNDIP, Semarang, 11 September.

Indriyati \& Wibowo, L. (2008). Keragaman dan kemelimpahan Collembola serta Arthropoda tanah di lahan sawah organik dan konvensional pada masa bera. J. HPT Tropika, 8(2), 110-116.

Jamilah. (2011). Degradasi lahan di daerah aliran sungai Batang Gadis. Medan: FP USU.

Janssens, F. (2010). Checklist of Collembola of the world. Retrieved from http://www.collembola.org.

Kamal, M., Yustian, I. \& Rahayu, S. (2011). Keanekaragaman jenis Arthropoda di Gua Putri dan Gua Selabe kawasan karst Padang Bindu, OKU Sumatera Selatan. Jurnal Penelitian Sains, 14(1), 3337.

Kanal, A. (2004). Effects of fertilisation and edaphic properties on soil-assosiated Collembola in crop rotation. Agronomy Research, 2(2), 153-168.

Kim, J. T., Park, K. H., Rojanavngse, V. \& Lee, B. H. (1999). Systematic study on Collembola (Insecta) from Thailand, I. Eight new species of Dicranocentroides (Paronellidae) and Lepidocyrtus (Entomobryidae). Nat. Hist. Bull. Siam Soc., 47: 207224.
Krebs, C.J. (1989). Ecological methodology. Columbia: Harper Collins Publishers.

Leksono, A.S. (2011). Keanekaragaman hayati. Malang: UB Press.

Noerdjito, W.A. (2010). Dampak kegiatan manusia terhadap keanekaragaman dan pola distribusi serangga di Gunung Salak. Bogor: Pusat Penelitian Biologi LIPI.

Odum, E.P. (1998). Dasar-dasar ekologi. Yogyakarta: Gadjah Mada University Press.

Price, P.W. (1997). Insect ecology. $3^{\text {rd }}$ Edition. New York: Wiley Interscience.

Priyono, B. \& Abdullah, M. (2013). Keanekaragaman jenis kupu-kupu di Taman Kehati UNNES. Biosaintifika, 5(2), 76-81.

Rahmadi, C. \& Suhardjono, Y.R. (2007). Arthropoda gua di Nusakambangan Cilacap, Jawa Tengah. Zoo Indonesia, (16):21-29.

Rahmadi, C., Suhardjono, Y.R. \& Andayani, I. (2004). Collembola lantai hutan di kawasan hulu Sungai Tabalong Kalimantan Selatan. Biota, IX:179-185.

Rahmawati, Y. (1999). Komunitas Collembola lantai kebun salak di Paraksari Yogyakarta. Skripsi. Yogyakarta: Biologi UAJY.

Suhardjono, Y.R., Deharveng, L. \& Bedos, A. (2012). Collembola (ekorpegas). Bogor: Vegamedia.

Suharjono. (1992). Dinamika populasi dan preferensi Collembola terhadap kapang tanah di hutan pinus Lembang. Tesis. Bandung: FBIO ITB.

Suin, N.M. (2012). Ekologi hewan tanah. Cetakan IV. Jakarta: Bumi Aksara.

Suwarno, Fuadi, S. \& Mahmud, A.H. (2013). Keragaman dan kelimpahan kupu-kupu pasca tsunami di kawasan Sungai Sarah, Aceh Besar. Makalah Semirata FMIPA UNILA, Bandar Lampung.

Suwondo. (2002). Komposisi dan keanekaragaman Mikroorthropoda tanah sebagai Bioindikator karakteristik biologi pada tanah gambut. Pekanbaru: FKIP UNRI.

Trisnawati, I.D.T. \& Subahar, T.S. (2011). Kelompok trofik pada komunitas arthropoda tajuk dan lantai hutan di Hutan Gunung Tangkubanparahu-Jawa Barat: Ilustrasi dengan Diagram Trofik Hipotetik. Berkala Penelitian Hayati, 17: 119-125.

Zeppelini, D., Bellini, B.C., Crea o-Duarte, A.J. \& Herna'ndez, M.I.M. (2009). Collembola as bioindicators of restoration in mined sand dunes of Northeastern Brazil. Biodivers Conserv, (2009)18:1161-1170. 